\title{
THE STUDY OF SME'S PROFITABILITY AND ITS RELATION TO THE AVAILABILITY OF ELECTRICAL ENERGY IN TELUK WONDAMA REGENCY
}

\author{
Irawantho \\ Local Government of Teluk Wondama Regency, West Papua \\ Alimuddin, Nursini \\ Faculty of Economics and Business, Universitas Hasanuddin
}

\begin{abstract}
This research aimed to investigate the effect of electrical energy costs, the business capital, and the total of the laborers on the profits of the Micro Small and Medium Enterprises in Teluk Wondama Regency.

This research used the regression equation. The Objects of the study were Micro Small and Medium Enterprises who were business actors who were impacted doe to the establishment of the cooperation between the Government of Teluk Wondama Regency and PT. PLN in term of supply of the electrical energy. The data were collected using the technique of questionnaires distributed to 90 micro small and medium enterprises. The types of data used were the primary data. The analysis model used in this research was the multiple linear regression.

The research result indicated that (1) The electrical costs had a positive and significant effect on the profits of SME in Teluk Wondama Regency; (2) The business capital had a positive and significant effect on the profits of SME in Teluk Wondama Regency; (3) The number of laborers had a positive and significant effect on the profits of SME in Teluk Wondama Regency. The roles of the three factors together had the effect of $46.5 \%$, while the rest of about $53.5 \%$ was determined by other factors.
\end{abstract}

Keywords: electrical costs, business capital, number of laborers, Profits of SME 


\section{INTRODUCTION}

Development is a human effort through the empowerment of natural resource and environment with the aim is to improve its standard of living (Purwono, 2002). Economic development is a change occurs continuously through a series of process combination to achieve something better by the improvement of income per capita lasts forever in the long term. Economic development has three important characteristics; the first is a process of change which happens continuously and sustainably. The change is a follow up of previous changes. Regional development is hoped to bring positive impact on economic growth. Regional economic growth can be reflected from the change of PDRB in a region (Suryono, 2010).

The success or failure of economic development in a region can be seen from the level of welfare of the community which is marked by the increase of consumption due to the improvement of income. The fact in the field is the dissemination of welfare is never obtained due to several things: internal problems such as discrepancy between humans, discrepancy between regions, both regional and national (Putri Wahyuni et al., 2014).

High economic development encourages the improvement of the community need for basic infrastructure such as water, electricity, and road. However, the availability of basic infrastructure is a challenge for the regional government, particularly related to its finance. The low capacity of regional fiscal and the minimum contribution of original regional revenue requires the government to look for other sources of finance. Infrastructure plays an important role as a mediator between the economic and social system in human life and environment. The condition is to maintain harmony of life which means that the lack of infrastructure has no impact on human. But it also does not exceed without considering the support of natural environment since it will damage the nature and at the end will have an impact on human and other living creatures.

There are some researches focusing on the impact of infrastructure on economy that have been done with different variations of result. Sibarani (2002: 32) found that infrastructure such as electricity and education has a positive and significant impact on income per capita of Indonesian community; whereas, road and telephone variables were not significant. The policy of infrastructure development is centered in Java and western part of Indonesia causes disparity of income per capita in each region in Indonesia, especially eastern part of Indonesia. The result of this study describes the importance of infrastructure development as a government effort besides improving regional economic growth to encourage the realization of welfare of the community evenly. Fair infrastructure development will be a constraint in the disparity of development between the regions.

Mawardi's research result (2004: 22) indicates that infrastructure has a positive impact for economic development. The finding is supported by CIDES (2007) and empirical study by Mustajab (2009: 211) predicted that one percent of increase in infrastructure investment contributes 0,3 percent on PDB. This supported the idea saying that sufficient and good quality infrastructure is a motor for sustainable economic development and eradication of poverty in Indonesia. For Teluk Wondama Regency, electricity infrastructure is one of the problems fully affects the acceleration of development 
as it is expected by the government and community which of course also affect the income of community through SME. According to Paulus Y.I (2006) the main problem causing Wondama still having an electricity crisis is the availability of oil fuel. The problem was not on the supply, but the unavailability of tank for big capacity. The study aims to analyze the relationship between capital, manpower, and the utility of electricity toward income of SME in Teluk Wondama Regency.

\section{LITERATURE REVIEW}

\section{Development and Economic Growth}

Basically development is a physical activity and also state of mind of a community through particular combination of social process, economy, and institution to make a better life (Todaro and Smith, 2011). In order to cover the better life, development in all community at least has three objectives:

- The improvement of the availability and expansion of goods distribution, basic needs for life such as food, housing, health, and protection.

- The improvement of life standard which is not only the improvement of income but also the availability of more employment, better education, and greater attention to cultural values and humanity. In general, these cannot only improve material welfare but also increase self esteem of individual and nation.

- The expansion of available economic and social choices for individual and nation in general which not only free them from impeded attitude and feeling which depends on other people and nations but also from various factors causing ignorance and poverty.

\section{Theory of Neo-classic Growth}

Theory of neo-classic was first developed by Ramsey (1928) but was popularized by Solow (1956). The theory assumes that the change of exogenous technology, constant returns to scale, substitutability between capital and manpower and diminishing capital marginal productivity. Model of neoclassic growth develops three important points. First, improvement of capital ratio-capital to labor ratio, e.g. investment ratio and saving is a key source of economic growth. Second, economy at last will come to the situation in which there is no more capital improvement that will create economic growth (steadystate) except there is a technological development to obtain production condition with lower resources. In economy which has no technological growth, income can be determined by the amount of capital and manpower. Based on variable in this production function, there are two models of growth, namely model of growth without development of technology and model of growth with development of technology.

\section{Harrod-Domar Theory of Growth}

Harold -Domar theory of growth was developed by Evsey Domar and Sir Roy F. Harrod (Adrian and Zulfahmi, 2007). This theory is an expansion of Keynes theory by including long-term economic problems and trying to show requirements needed to make steady economic growth and develop.

Harrod-Domar theory has several assumptions:

- Economy in full employment.

- Economy consists of two sectors: household sector and company sector.

- The amount of community saving is proportional with the amount of national income which means the function of saving begins from zero point.

- The tendency to saving (marginal propensity to save(MPS) fixed amount, 
also the ration between capital-output ratio (COR) and incremental capitaloutput ratio (ICOR).

According to Harrod-Domar theory, each economy can put aside a certain proportion of the national income only to replace damaged capital goods. But in order to grow the economy, new investment is needed as an additional capital stock. If it is assume that there is a direct economic relation between the amount of capital stock $(\mathrm{K})$ and total output (Y), each additional net capital stock (new investment) will cause total output increase according to output capital ratio. This relation is known as capital output capital ratio (COR). Investment in Harrod-Domar theory of growth is formulated as a change of capital stock related directly to total output.

\section{Factors Determining the Improvement of SME \\ Business Capital}

In doing business, one supporting factor needed is capital. It is like building a house and capital will be a foundation of the house to be built. Like wise the effect of capital on a business, its existence is initial business foundation to be built. Some capital needed in doing business: strong will, experience, courage, knowledge, net working, and money, but most people have a constraint in initiating a business because they have problem in getting money.

Capital is very important in doing a business. The amount of capital needed depends on the size of business to be built. Business consultants in general divide small capital business into tangible capital and intangible capital. Tangible capital is a real capital both in the form of moving goods and unmoving goods. The examples of moving goods are motor bike, production machine, etc.

\section{Human Resource/Manpower}

Economic development must be done to make a developed country. The economic development itself means a process of total income improvement and income per capita by considering the increase of population accompanied by fundamental change in economic structure of a country and dissemination of income for population of a country (Bannock, 2004). In economic development theory and economic growth, there are determining elements supporting the economic development according to Bannock (2004), that is human resource.

\section{RESEARCH METHOD}

\section{Research Design}

This study is qualitative aims to test the impact of cooperation between PT.PLN (Persero) and government of Teluk Wondama Regency in the preparation of electrical infrastructure and other factors such as capital and human resource.

\section{Research Location and Time}

The study was conducted inn Teluk Wondama Regency. The location was selected based on the availability of data and it is the place where the researcher works as a public servant. The collection and analysis of data were done in 2015 up to 2017. The study lasted for three months.

The time was used to obtain data and information from the object of study and other relevant data until analysis of data and arrangement of research results.

\section{Population, Sample, and Sampling Technique}

The population of the study was the actors of SME in Teluk Wondama Regency. The number of samples of the study was 90 samples representing a number of data source consisting of nine types of business (food stall, various kinds of goods, printing, photo copy, clothing, tofu and soybean, animal husbandry, fishery, and electric tools). 
The technique used in selecting the samples was non-probability sampling in which no opportunity was given to each population to be selected as sample. The technique used was judgment sampling that is the samples were selected based on the objective of the study or the existing study problem.

\section{Types and Source of Data}

Types and source of data are the most important factors in collecting the data. The types of data used in the study were subject data or belong to quantitative data.

The source of data used in this study was primary data. Primary data according to Indriantoro and Supomo (2009) are data obtained directly from the original source. The primary data were obtained by giving questionnaires directly to respondents of SME actors.

\section{Method of Data Collection}

The data of this study were collected by:

- Interview, a method used to collect data by interviewing the SME unit.

- Observation, by doing observation directly to object of the study.

- Questionnaire, by distributing questionnaire to selected respondents.

\section{Operational Definition}

The variables of this study consist of exogen and endogen variables. Endogen variable is the profit of SME business and exogen variable is electricity cost, business capital, number of manpower, and cost of manpower.

Operational definition and variables used in this study are:

- Cost of electricity

Cost of electricity is a cost to run the business on the average per month in rupiah unit.

- Business Capital

Business capital is the amount of fund used in initiating the business in rupiah unit.

- Number of Manpower
Manpower is the use of employees work or employed in doing business activity measured by unit of person.

- SME Profit

SME profit is business profit received on the average per month that is the difference of good and service sale turnover (total revenue) and costs used (total cost) measured in rupiah on the average per month.

\section{Instrument of the Study}

The instrument of the study is questionnaire distributed to respondents that is SME in Teluk Wondama Regency with the number of 90 respondents of SME.

\section{Model of Analysis}

In order to find out the effect of electricity cost, business capital, and number of manpower on the SME profit in Teluk Wondama Regency, regression equation was used and the appropriate analysis used was multiple regression analysis.

Based on the functional correlation in the conceptual framework the functional equation formed is:

$$
\mathrm{Y} 1=\mathrm{f}\left(\mathrm{X} 1, \mathrm{X}_{2}, \mathrm{X}_{3}\right)
$$

In which:

$\begin{array}{ll}\mathrm{Y} 1 & =\text { net profit } \\ \mathrm{X} 1 & =\text { cost of electricity } \\ \mathrm{X} 2 & =\text { business capital } \\ \mathrm{X}_{3} & =\text { number of }\end{array}$

manpower

\section{RESEARCH RESULT}

Age

In general the SME actors in Teluk Wondama Regency belong to productive age between 31 and 40 years as many as 66 respondents or as much as 73.33 percent. Whereas the age under 31 years as many as 9 respondents or 10.00 percent and more than 40 years old as many as 15 respondents or 16.67 percent.

Table 1. Distribution of Respondents by Age

\begin{tabular}{llll}
\hline No & Age & Number & Percentage \\
\hline
\end{tabular}




\begin{tabular}{cccc}
\hline & Less than 20 years & - & 0.00 \\
\hline 2 & $21-25$ years & 3 & 3.33 \\
\hline 3 & $26-30$ years & 6 & 6.67 \\
\hline 4 & $31-35$ years & 47 & 52.22 \\
\hline 5 & $36-40$ years & 19 & 21.11 \\
\hline 6 & More than 40 years & 15 & 16.67 \\
\hline & Total & 90 & 100.00 \\
\hline
\end{tabular}

Source: Processed primary data, 2017

With the proportion of oldest age in productive category, this will become specific capital factor to develop SME in Teluk Wondama Regency by synchronizing the role of business capital, manpower and electric energy. This means that the productive age between 31 and 40 years will give a significant effect on SME actors supported by the availability of manpower, capital adequacy, and support of energy.

\section{Level of Education}

Human resource plays an important role in a business organization. Each business organization needs qualified and competent human resource in running the wheel of business operation. The company must be able to choose human resource that can play an active role effectively and efficiently. In order to be able to choose qualified human resource according to qualification of the company, management of human resource is necessary.

Table 2. Distribution of Respondents by Education

\begin{tabular}{cccc}
\hline No & Education & Number & Percentage \\
\hline 1 & SD & - & 0.00 \\
\hline 2 & SLTP & 39 & 43.33 \\
\hline 3 & SLTA & 46 & 51.11 \\
\hline 4 & S 1 & 5 & 5.56 \\
\hline 5 & Others & - & 0.00 \\
\hline & Total & 90 & 100.00 \\
\hline
\end{tabular}

Source: Processed primary data, 2017

Table 2 indicates that the average respondents of SME actors in Teluk Wondamo Regency have SLTP and SLTA education with the number of respondents was 85 or 94.44 percent and the rest 5 respondents or 5.56 percent have $\mathrm{S} 1$ education.

\section{Number of Dependents}

From consumption point of view, the number of dependents of each respondent has an effect on the income received and to be used for other allocation function such as saving and investment. Based on data in Table 3, the number of 75 or 83.3percent of respondents have $3-5$ dependents and the rest has more than 5 (five) dependents.

Table 3. Distribution of Respondents by Number of Dependents

\begin{tabular}{cccc}
\hline No & Dependent & Number & Percentage \\
\hline 1 & 2 persons & - & 0.00 \\
\hline 2 & $3-5$ persons & 75 & 83.33 \\
\hline 3 & More than 5 persons & 15 & 16.67 \\
\hline & Total & 90 & 100.00 \\
\hline
\end{tabular}

Source: Processed primary data, 2017

\section{Characteristics of Business Form of Business}

Based on data in Table 4, 80 or 88.89 percent of SME have individual business form and other 10 or 11.11 percent are corporations.

Table 4. Distribution of SME Actors by Form of Business

\begin{tabular}{cccc}
\hline No & Form of Business & Number & Percentage \\
\hline 1 & Form of Business & 80 & 88.89 \\
\hline 2 & $\begin{array}{c}\text { Corporation } / \\
\text { Partnership }\end{array}$ & 10 & 11.11 \\
\hline & Total & 90 & 100.00
\end{tabular}

Source: Processed primary data, 2017

In relation to the development of business done, it can be said that SME actors in Teluk Wondama Regency still manage small scale enterprises. But in line with the development, they need to put into consideration the expansion of their business.

\section{Types of Business}

Based on data in Table 5, there are 26 or 28.89 percent of the SME actors engage in various kinds of goods. There are 17 or 18.89 percent manage food 
stalls. In relation to the needs of the community, both kinds of business have a role in supporting the fulfillment of the community basic needs.

Table 5. Distribution of the SME Actors by Types of Busi-

\begin{tabular}{cccc}
\multicolumn{5}{c}{ ness } \\
\hline No & $\begin{array}{c}\text { Types of } \\
\text { Business }\end{array}$ & Number & Percentage \\
\hline 1 & Food Stall & 17 & 18.89 \\
\hline 2 & $\begin{array}{c}\text { G e n e r a l } \\
\text { Goods }\end{array}$ & 26 & 28.89 \\
\hline 3 & Printing & 8 & 8.89 \\
\hline 4 & Photo Copy & 10 & 11.11 \\
\hline 5 & $\begin{array}{c}\text { Ready Cloth- } \\
\text { ing }\end{array}$ & 16 & 17.78 \\
\hline 6 & $\begin{array}{c}\text { Tofu and } \\
\text { Soybean }\end{array}$ & 1 & 1.11 \\
\hline 7 & $\begin{array}{c}\text { Animal Hus- } \\
\text { bandry }\end{array}$ & 4 & 4.44 \\
\hline 8 & Fishery & 2 & 2.22 \\
\hline 9 & $\begin{array}{c}\text { E l e c t r i c } \\
\text { Tools }\end{array}$ & 6 & 6.67 \\
\hline & Total & 90 & 100.00 \\
\hline
\end{tabular}

Source: Processed primary data, 2017

Other types of business that play a role in supporting the fulfillment of secondary need such as ready clothing are 16 or 17.78 percent, photo copy and printing are 10 or 11.11 percent and 8 or 8.89 percent respectively, animal husbandry 4 or 4.44 percent, fishery 2 or 2.22 percent, 1 or 1.11 percent engage in tofu and soybean, and the rest 6.67 percent engage in electric tools.

\section{Length in Doing Business}

In general the SME actors as respondents of the study have engaged in their business for more than 10 years as many as 37 persons or 41.11 percent, 32 of them or 35.56 percent have engaged in this business for $7-10$ years, 12 or 13.33 percent have engaged in the SME for $5-6$ years and the rest 9 persons or 10 percent have just engaged in this business for $2-4$ years.

Table 6. Distribution of the SME Actors by Length of Business No Length of Business Number Percentage

\begin{tabular}{cccc}
\hline 1 & Less than 2 years & - & 0.00 \\
\hline 2 & $2-4$ years & 9 & 10.00 \\
\hline 3 & $5-6$ years & 12 & 13.33 \\
\hline 4 & $7-10$ years & 32 & 35.56 \\
\hline 5 & More than 10 years & 37 & 41.11 \\
\hline & Total & 90 & 100.00 \\
\hline
\end{tabular}

Source: Processed primary data, 2017

\section{Characteristics of Research Variables \\ Electric Cost Variable}

The availability and sufficiency of power is another factor determining the development of business and economy of the community in general. Since the existence of Teluk Wondama Regency government policy which cooperates with PT. PLN in the preparation of electricity energy, the productivity level of the SME actors is higher compared to the previous period.

Electric cost spent by the SME in doing their business is on the average can be seen in Table 7.

Table 7. Distribution of the SME Actors by Cost of Electric Energy

\begin{tabular}{cccc}
\hline No & Electric Cost & Number & Percentage \\
\hline 1 & $\leq 500.000$ & 16 & 17.77 \\
\hline 2 & $500.000-1.000 .000$ & 37 & 41.11 \\
\hline 3 & $1.000 .000-1.500 .000$ & 18 & 20.00 \\
\hline 4 & $1.500 .000-2.000 .000$ & 14 & 15.56 \\
\hline 5 & $\geq 2.000 .000$ & 5 & 5.56 \\
\hline & Total & 90 & 100.00 \\
\hline
\end{tabular}

Source: Processed primary data, 2007

Table 7 shows that 16 SME or 17.77 percent operate their business by spending electric cost under Rp 500.000 per month, 37 SME or 41.11 percent spend between Rp 500.000 to Rp 1.000.000, 18 SME or 20.00 percent spend between $\mathrm{Rp}$ 1.000.000 to Rp 1.500.000, 14 SME or 15.56 percent spend between $\mathrm{Rp}$ 1.500.000 to $\mathrm{Rp} \mathrm{Rp} \mathrm{2.000.000} \mathrm{and} 5$ SME or 5.56 percent spend more than Rp 2.000.000.

\section{Business Capital Variable}


Table 8. Distribution of the SME Actors by Amount of Business Capital

\begin{tabular}{cccc}
\hline No & Amount of Capital & Number & Percentage \\
\hline 1 & $\leq 500.000$ & 16 & 17,77 \\
\hline 2 & $\begin{array}{c}500.000- \\
1.000 .000\end{array}$ & 37 & 41,11 \\
\hline 3 & $\begin{array}{c}1.000 .000- \\
1.500 .000\end{array}$ & 18 & 20,00 \\
\hline 4 & $\begin{array}{c}1.500 .000- \\
2.000 .000\end{array}$ & 14 & 15,56 \\
\hline 5 & 2.000 .000 & 5 & 5,56 \\
\hline & Total & 90 & 100,00 \\
\hline
\end{tabular}

Source: Processed primary data 2017

Most of the SME actors began their business by very small capital as can be seen in Table 8 . There are 94.33 percent of them began their business below Rp 100.000.000 and those who began their business with more than $\mathrm{Rp}$ 100.000.000 are only 5.67 percent. This is due to Teluk Wondama Regency which was newly established in 2002 so that the existing SME actors are not professional.

\section{Manpower Variable}

In order to operate and develop their business, the SME actors have employed several employees as can be seen in Table 9. In general $40 \mathrm{SME}$ or 44.44 percent employ $3-4$ persons and 14 SME or 15.56 percent employ more than 5 persons, and $36 \mathrm{SME}$ or 40.00 percent employ $1-2$ persons.

Table 9. Distribution of SME Actors by Number of Manpower

\begin{tabular}{ccc}
\hline $\begin{array}{l}\text { Number of } \\
\text { Manpower }\end{array}$ & Number & Percentage \\
\hline 2 persons & 36 & 40.00 \\
\hline $\begin{array}{c}3-4 \text { per- } \\
\text { sons }\end{array}$ & 40 & 44.44 \\
\hline 5 persons & 14 & 15.56 \\
\hline Total & 90 & 100.00 \\
\hline
\end{tabular}

Source: Processed primary data, 2017

\section{Hypothesis Testing}

Analysis of Correlation and Determination
Table 10.Results of Correlation and Determination Analysis

\begin{tabular}{ll}
\hline Regression Statistics & \\
\hline Multiple R & 0.681 \\
R, Square & 0.464 \\
Adjusted R. Square & 0.445 \\
Standard Error & 1793089.778 \\
Observations & 90 \\
\hline
\end{tabular}

Table 10 above indicates the computation of Multiple correlation ( $R$ ) yields value as much as 0.861 . This indicates that there is a significant correlation between electric cost variable (X1), business capital (X2), number of manpower (X3) and SME profit $(\mathrm{Y})$ in Teluk Wondama Regency.

The result of the study indicates that the value of $\mathrm{R} 2$ as much as 0.464 means the electric cost (X1), business capital (X2) and number of manpower ( $\mathrm{X}_{3}$ ) have an important role in determining the SME profit in Teluk Wondama Regency. This indicates that the role of the three factors above have contribution as much as $46.5 \%$ and the rest about $53.5 \%$ is determined by other factors besides the three factors above.

\section{Regression Analysis}

Regression analysis was used to find out the effect of independent variable (X) on dependent variable (Y)

Table 11. Regression Analysis Results

\begin{tabular}{lllllll}
\hline Model & $\begin{array}{l}\text { Coeffi- } \\
\text { cients }\end{array}$ & $\begin{array}{l}\text { Standard } \\
\text { Error }\end{array}$ & t Stat & P-value & $\begin{array}{l}\text { Lower } \\
95 \%\end{array}$ & $\begin{array}{l}\text { Upper } \\
95 \%\end{array}$ \\
\hline $\begin{array}{l}\text { Inter- } \\
\text { cept }\end{array}$ & $\begin{array}{l}3872963 . \\
393\end{array}$ & $\begin{array}{l}567573 . \\
461\end{array}$ & 6.824 & 0.000 & $\begin{array}{l}2744664 . \\
695\end{array}$ & $\begin{array}{l}5001262 . \\
091\end{array}$ \\
\hline $\begin{array}{l}\text { Electric } \\
\text { cost } \\
\text { (X1) }\end{array}$ & 0.754 & 0.345 & 2.184 & 0.032 & 0.068 & 1.440 \\
\hline $\begin{array}{l}\text { Busi- } \\
\text { ness } \\
\text { capital } \\
\text { (X2) }\end{array}$ & 0.012 & 0.005 & 2.333 & 0.022 & 0.002 & 0.022 \\
\hline $\begin{array}{l}\text { Num- } \\
\text { ber of }\end{array}$ & 816913. & 187002. & 2.764 & 0.007 & 145165. & 888661. \\
$\begin{array}{l}\text { Man- } \\
\text { power } \\
\text { (X3) }\end{array}$ & 207 & & & 809 & 976 \\
\hline \multicolumn{5}{c}{ Source: Processed data, 2017 } & & \\
\hline
\end{tabular}

Table 11 above indicates the results of regression analysis, so that regression 
equation obtained is as follows:

$$
\begin{aligned}
& \mathrm{Y}=\mathrm{a}+\mathrm{b} 1 \mathrm{X} 1+\mathrm{b} 2 \mathrm{X}_{2}+\mathrm{b}_{3} \mathrm{X}_{3}+\mathrm{e} \\
& \mathrm{Y}=3.873+0.754 \mathrm{X} 1+\mathrm{O} .012 \mathrm{X} 2+ \\
& 5169913.893 \mathrm{X}_{3} \\
& \text { The results of regression equation }
\end{aligned}
$$
analysis above are:

- The value of regression coefficient for electric cost variable (X1) is 0.754 ; this indicates that the SME in Teluk Wondama Regency need source of electric energy for private business to improve their income. When the source of electric power is improved to 1 unit, the income will increase to 0.754 .

- The value of regression coefficient for business capital (X2) is 0.012; this indicates that the SME in Teluk Wondama Regency also need business capital to improve their income. When the manpower is 1 unit, the income will improve to 0.012 .

- The value of regression coefficient for the number of manpower $\left(\mathrm{X}_{3}\right)$ is 0.761 indicates that the SME in Wondama Regency fully need electric to improve their income. When the electric utility is increased to 1 unit, it will increase the SME profit as much as 516.9913.893.

\section{F-test Analysis}

The results of F-test analysis can be seen in Table 12 indicating that the F-test result shows 24.769 and is significant as much as 0.000. This means that collectively, capital variable (X1), human resource (X2), and electric utility (X3) have a very significant effect on the SME income in Teluk Wondama Regency.

Table 12 F-test Analysis Results ANOVA

\begin{tabular}{llclll}
\hline & df & SS & MS & F & $\begin{array}{l}\text { Signifi- } \\
\text { cance F }\end{array}$ \\
\hline Regression & 3 & $2.39 \mathrm{E}+14$ & $7.96 \mathrm{E}+13$ & 24.7694 & \\
Residual & 86 & $2.77 \mathrm{E}+14$ & $3.22 \mathrm{E}+12$ & & 0.000 \\
Total & 89 & $5.15 \mathrm{E}+14$ & & & \\
\hline
\end{tabular}

\section{t-test Analysis}

The result of t-test analysis is illustrated in Table 13 in which the three independent variables (X) have a significant value.

\begin{tabular}{lllll}
\multicolumn{5}{c}{ Table 13. t-test Analysis Results } \\
\hline & Coefficients & $\begin{array}{l}\text { Standard } \\
\text { Error }\end{array}$ & t Stat & P-value \\
\hline Intercept & 3872963.393 & 567573.461 & 6.824 & 2.764 \\
\hline $\begin{array}{l}\text { Electric } \\
\text { Cost (X1) }\end{array}$ & 0.754 & 0.345 & 2.184 & 0.032 \\
\hline $\begin{array}{l}\text { Business } \\
\text { Capital } \\
\text { (X2) }\end{array}$ & 0.012 & 0.005 & 2.333 & 0.022 \\
\hline $\begin{array}{l}\text { Number of } \\
\text { Manpower }\end{array}$ & 516913.893 & 187002.207 & 2.764 & 0.007 \\
(X3) & & & & \\
\hline
\end{tabular}

Source: Processed data, 2017

The analysis of t-test in Table 13 indicates the effect of electric power (X1) partially on the SME income (Y) as much as 2.184 and the significance is 0.032 is smaller than 0.05. This indicates that the electric cost has a significant effect on the SME profit.

The effect of business capital (X2) variable on the SME profit $(\mathrm{Y})$ can be seen from the result of $t$-test showing the figure 2.333 and is significant 0.002 and is smaller than 0.05 so that it can be said that it has a significant effect.

The number of manpower variable (X3) has a significant effect on the SME profit in Teluk Wondama Regency due to the t-test analysis showing the figure 2.764 which is significant 0.007 and is smaller than 0.05.

\section{Hypothesis Testing Results}

Table 14. Hypothesis Testing Results

\begin{tabular}{lllll}
\hline Variable & t-test & Sig. & Alfa & Remark \\
\hline $\begin{array}{l}\text { Electric } \\
\text { Cost (X1) }\end{array}$ & 2.184 & 0.032 & 0.05 & Significant \\
\hline $\begin{array}{l}\text { Business } \\
\text { Capital } \\
\text { (X2) }\end{array}$ & 2.333 & 0.022 & 0.05 & Significant \\
\hline $\begin{array}{l}\text { Number of } \\
\text { Manpower }\end{array}$ & 2.764 & 0.007 & 0.05 & Significant \\
\hline
\end{tabular}

Source: Processed data, 2017

By looking at Table 14, the hypothesis testing analysis can be explained as 
follows:

- Hypothesis 1 states there is a positive significant effect of electric cost on the SME profit in Teluk Wondama. The electric cost variable (X1) has a positive and significant effect on profit with the value sig. 0.032 which is smaller than the value of alfa 0.05; therefore, the hypothesis is accepted.

- Hypothesis 2 indicates there is a positive and significant effect of business capital (X2) on the SME profit in Teluk Wondama. The business capital (X2) has appositive and significant effect on the profit with the value sig. 0.022 which is smaller than the value of alfa 0.05; therefore, the hypothesis is accepted.

- Hypothesis 3 indicates there is a positive and significant effect of the number of manpower on the SME profit in Teluk Wondama Regency; The number of manpower (X3) variable has a positive and significant effect on the profit with the value sig. 0,007 which is smaller than the value of alfa 0.05; therefore, the hypothesis can be accepted.

\section{DISCUSSION OF THE RESULTS OF ANALYSIS}

According to the scope of the discussion of the study, the discussion is focused on the effect of electric cost, business capital, and number of manpower on the SME profit.

Based on the test done to several hypotheses in this study, it can be found out that simultaneously (F test) of the three independent variables: electric cost, business capital, and number of manpower have a significant effect on the SME profit. Partially (t-test analysis) can be concluded that the three variables also have a significant effect on the SME profit.

\section{The Effect of Electric Cost on the SME Profit}

The policy taken by the government of Teluk Wondama Regency cooperating with PT. PLN in preparing the sustainable source of electric energy has made a number of changes including the SME. This is in line with the information from the SME actors who have used electricity for daily needs and operational need for the development of their business.

Based on the results of data processing, it indicates that electric cost has an effect on the SME profit in which the SME actors before using electricity from PT.PLN was not significant. But after the use of electricity from PT.PLN, it has a significant effect on the business profit. This is in line with the research result done by Devi Valeriani (2011) in which the result indicates that simultaneously tourism, transportation and electricity have a significant effect on the income per capita of the community in Bangka Regency.

The availability of electric energy affecting the electric cost is basically a very important factor in the sustainability of a business activity. The t-test analysis shows that the electric cost has an effect on business profit with he value of tcount as much as 2.184 with significant probability as much as 0.032 .

\section{The Effect of Business Capital on the SME Profit}

The determination of capital source is not an easy problem, moreover if it is related to business need. There are some alternatives of the source of business, but what necessary to know is how to get it and how to manage it properly. Based on the data processing result in appendix 6 , it indicates that business capital has a positive and significant effect on the SME profit in which the business capital affects the business profit with the value of tcount as much as 2.333 with the significant probability as much as 0.022 . 
This is in line with the hypothesis that business capital has a positive effect on business profit. Low access to micro business to formal loan institutions tends to use the business capital of one's own capital or other sources such as family, relative, trader, middle man or even money lender.

\section{The Effect of the Number of Manpower on the SME Profit}

Based on the data processing, it indicates that business capital has a positive and significant effect on the business profit with the value of tcount as much as 2.764 with the significant probability as much as 0.007 . The correlation between manpower and business profit or what is expected by the theory. This is in line with the Schroeder's research in Herawati (2008) in which he states that in the management of human or manpower is an important thing in operation because there is nothing that can be settled without humans who work on it. Managing the manpower properly and efficiently is the key to success as a part of the operation.

\section{CONCLUSIONS AND SUGGESTIONS}

\section{Conclusions}

- Electric cost has a positive and significant effect on the SME profit in Teluk Wondama Regency.

- Business capital has a positive and significant effect on the SME profit in Teluk Wondama Regency.

- The number of manpower has a positive and significant effect on the SME profit in Teluk Wondama Regency

\section{Suggestions}

- The regional government of Teluk Wondama Regency should sustain the availability of electric energy for the existence of SME.

- Capital owned by SME is very limited; therefore, the regional government of Teluk Wondama can be a facilitator of micro business in the form of assistance or provider of warranty in banks or other financial institutions in order to improve the turnover of business capital which has an effect on the improvement of the SME profit in Teluk Wondama Regency.

\section{REFERRENCE}

Ardiana, I. A Brahmayanti, Subaendi. 2010. Kompetensi SDM SME dan Terhadap Kinerja SME di Surabaya. Jurnal Manajemen dan Kewirausahaan. Vol.12, No. 1

Bannock. G. R. E, Baxter dan Evan D. 2004. A Dictionary of Economics. Inggris: Penguin Books Ltd.

Chittithaworn, C. et al. 2011. Factors Affecting Business Success of Small \& Medium Enterprises (SMEs) in Thailand. Asian Social Science, Vol. 7, No. 5 .

CIDES (Center for Information and Development Studies). 2007. "Pengaruh Faktor-faktor Instituional dan Infrastruktur." Selasa, 27 November.

Haris, A. 2009. Pengaruh Penatagunaan Tanah Terhadap Keberhasilan Pembangunan Infrastruktur dan Ekonomi. http://www.bappenas. go.id/node/71/1195

Harry Kurniadi Atmaja dan Kasyful Mahalli. 2015. Pengaruh Peningkatan Infrastruktur Terhadap Pertumbuhan Ekonomi di Kota Sibolga. download. portalgaruda. org articlephp? article $=381844 \&$ val $=4119 \&$ title. Di akses pada tanggal 16 Maret 2017.

I Gusti Ayu Putri Wahyuni, Made Sukarsa, dan Nyoman Yuliarni. 2014. Pengaruh Pengeluaran Pemerintah dan Investasi terhadap Pertumbuhan Ekonomi dan Kesenjangan Pendapatan 
Kabupaten/Kota di Provinsi Bali. E-Jurnal Ekonomi dan Bisnis Universitas Udayana, Agustus, hal.1-20.

Inayah, N., Kirya, I. K, Suwendra, W. 2014. Pengaruh Kredit Modal Kerja Terhadap Pendapatan Bersih Usaha Kecil Dan Menengah (Ukm) Sektor Formal. E-Journal Bisma Universitas Pendidikan Ganesha Jurusan Manajemen, Vol. 2, No.6.

Islamy, I. 2017. Perluasan jenis proyek kerjasama pemerintah dengan badan usaha. Diakses dari http://www.bppk. kemenkeu.go.id/publikasi / artikel/149-artikel-kekayaannegar a-dan-perimb angankeuangan/21077-perluasan-jenisproyek-kerjasama-pemerintahdengan-badan-usaha-dalampenyediaan-infrastruktur. Pada tanggal 21 Maret 2017

Kodoatie, Robert J.2005. Pengantar Manajemen Infrastruktur. Pustaka Pelajar. Yogyakarta.

Lubis, H., Artikel: Can Public-Private Partnerships Still be Expected?, 2015

Mawardi, D.R. 2004. Hubungan antara infrastruktur ekonomi dan pertumbuhan PDRB di Jawa Timur dengan menggunakan pendekatan model persamaan produksi CobbDouglas. Thesis/Dissertation. Petra Christian Universitas Indonesia.

Muin, A. S. 2013. Kajian Kemampuan Usaha Dan Modal Sosial Serta Implikasinya Terhadap Kinerja Usaha Kecil Sektor Industri Di Sulawesi Selatan. Jurnal ASSETS, Vol. 3 No.1.

Mustajab, M. 2009. Infrastructure Investment in Indonesia: Process and Impact. PhD dissertation. Rijksuniversiteit. Netherlands.

Musran, M. 2010. Pengaruh Faktorfaktor Eksternal dan Internal
Terhadap SMEKecil dan Menengah

di Sulawesi Selatan. Jurnal Manajemen dan Kewirausahaan. Vol.12, NO.1

Narteh, B. 2013. 'SME bank selection and patronage behavior in the Ghanaian banking industry', Management Research Review, Vol. 36, No. 11, hal. 1061-1080.

N. Weil, David. 2009. Economic Growth. Second Edition, Pearson Addison Wesley

Partomo, T.S., 2009. Peranan UKM Dan Pentingnya Modal Ventura Di Indonesia. Policy Discussion Paper Series. Proceding. Jakarta: Universitas Trisakti.

Philomina, Q. 2012. Influence of Micro Finance and Small Loan Centre (MASLOC) on the Development of Small Scale Enterprises in the Wa Municipality. European Journal of Business and Management. Vol 4, No.1.

PT. Sarana Multiinfrastruktur Indonesia (Persero). 2014. Panduan Penyelenggaran Kerjasama Pemerintah - Swasta (KPS) dalam penyediaan infrastruktur

Perpres No.67 tahun 2005 tentang Kerjasama Pemerintah dengan Badan Usaha dalam Penyediaan Infrastruktur

Perpres No. 56 tahun 2011 tentang Perubahan Kedua atas Perpres No.67 tahun 2005 tentang Kerjasama Pemerintah dengan Badan Usaha dalam Penyediaan Infrastruktur

Perpres No. 66 tahun 2013 tentang Perubahan Ketiga atas Perpres No.67 tahun 2005 tentang Kerjasama Pemerintah dengan Badan Usaha dalam Penyediaan Infrastruktur

Perpres No.38 tahun 2013 tentang Kerjasama Pemerintah dengan Badan Usaha dalam Penyediaan 
Infrastruktur

Rante, Y. 2010. Pengaruh Budaya Etnis dan Perilaku Kewirausahaan Terhadap Kinerja SMEKecil Agribisnis di Provinsi Papua. Jurnal Manajemen Dan Kewirausahaan, Vol.12, No. 2, hlm : 133-141.

Rindang Bangun Prasetyo. 2008. Ketimpangan dan Pengaruh Infrastruktur terhadap Pembangunan Ekonomi Kawasan Barat Indonesia (KBI). Departemen Ilmu Ekonomi Fakultas Ekonomi dan Manajemen Institut Pertanian Bogor. Tidak dipublikasikan

Rindang Bangun Prasetyo dan M. Firdaus. 2009. Pengaruh Infrastruktur pada Pertumbuhan Ekonomi Wilayah Indonesia. Jurnal Ekonomi dan Kebijakan Pembangunan, 2(2): 222-236.

Riyanto, B. 2001. Dasar-dasar Perusahaan. Yogyakarta: Yayasan Penerbit

Rencana Pembangunan Jangka Menengah Nasional 2015-2019

Safar Iqbal dan Areef Suleman. 2010. Indonesia; Kendala Kritis bagi Pembangunan Infrastruktur. Islamic Development Bank

Sibarani, M.H.M., 2002. Kontribusi Infrastruktur terhadap Pertumbuhan Ekonomi Indonesia. Tesis Magister Sains. Program Pascasarjana, Universitas Indonesia, Jakarta.

Sukirno, Sadono. 2000. Ekonomi Pembangunan Proses, Masalah dan Dasar Kebijakan Pembangunan. UI-Press. Jakarta.

Stam, W., Souren A. Tom E., 2013. Social capital of entrepreneurs and small firm performance: A meta-analysis of contextual and methodological moderators. Journal of Business Venturing, Vol. 05655, No.7, hlm :22.

Suryono, Wiratno Bagus, 2010. Analisis pengaruh pendapatan asli daerah, tingkat investasi dan tenaga kerja terhadap pdrb jawa tengah

Todaro, Michael P. and Smith, Stephen C. 2011. Economic Development. 11th Edition. Library of Congress Cataloging-in-Publication Data

Valeriani, D. 2011. Analisis Pengaruh Kebijakan Infrastruktur Terhadap Pendapatan Perkapita Masyarakat Kabupaten Bangka Provinsi Kepulauan Bangka Belitung. Diakses dari journal.ubb.ac.id/ index.php/ekonomi/article pada tanggal 21 Maret 2017

World Bank. 1994. World Development Reports: Infrastructure for Development. Oxford University Press, New York. Manajemen dan Rekayasa Infrastruktur. Pustaka Pelajar, Yogyakarta.

Yanuar, R., .2006. Kaitan Pembangunan Infrastruktur dan Pertumbuhan Output serta Dampaknya terhadap Kesenjangan di Indonesia. Tesis Magister Sains. Program Pascasarjana IPB, Bogor. 